\title{
Tape Device
}

National Cancer Institute

\section{Source}

National Cancer Institute. Tape Device. NCI Thesaurus. Code C50209.

A long, thin, flat, flexible material often used for measuring, binding or fastening, or as a recording medium. 